\title{
Antihyperglycemic Activity of Banana (Musa nana Lour.) Peel and Its Active Ingredients in Alloxan-Induced Diabetic Mice
}

\author{
Hongmei $\mathrm{Wu}^{1, \mathrm{a}}$, Feng $\mathrm{Xu}^{2, \mathrm{~b}}$, Junjie $\mathrm{Hao}^{3, \mathrm{c}}$, Ye Yang ${ }^{4, \mathrm{~d}}$ and Xiangpei Wang ${ }^{5, \mathrm{e}^{*}}$ \\ ${ }^{1}$ Guiyang College of Traditional Chinese Medicine, 50, Nanming District, Guiyang City, Guizhou \\ Province, Guiyang 550002, PR China \\ ${ }^{2}$ Guiyang College of Traditional Chinese Medicine, 50, Nanming District, Guiyang City, Guizhou \\ Province, Guiyang 550002, PR China \\ ${ }^{3}$ Baoshan of Traditional Chinese Medicine, 130, Taibao north road, Baoshan City, Yunnan Province, \\ Baoshan 678000, PR China \\ ${ }^{4}$ Guiyang College of Traditional Chinese Medicine, 50, Nanming District, Guiyang City, Guizhou \\ Province, Guiyang 550002, PR China \\ ${ }^{5}$ Guiyang College of Traditional Chinese Medicine, 50, Nanming District, Guiyang City, Guizhou \\ Province, Guiyang 550002, PR China \\ awhm0425@126.com, ${ }^{\mathrm{b}}$ xf333666999@sina.com, ${ }^{\mathrm{c}}$ 1733831005@qq.com, ${ }^{\mathrm{d}}$ yangye459@163.com, \\ wxp0123@126.com
}

Keywords: Banana peel, Musa nana Lour., lupenone, antihyperglycemic, $\beta$-sitosterol Abstract. Previous studies have found that banana flowers, leaves, pseudostems, roots, infructescence stalks, and peels (M. paradisiacal (Linn.)) have antihyperglycemic effect. The banana peel (Musa nana Lour.) might have the antihyperglycemic activity, its antihyperglycemic activity and active ingredients remain to be elucidated. In this paper, fresh banana peel was sequential extraction using solvents with decreasing polarity. Then, the ethyl acetate and petroleum ether extracts (EBP and PBP) were chosen to evaluate the antihyperglycemic activity in alloxan-induced diabetic mice. And the antihyperglycemic activity guided fractionation of compounds. The EBP displayed potent antihyperglycemic activity. lupenone and -sitosterol were separated from EBP. Animal experiments results indicated that lupenone could effective reduce blood glucose of diabetic mice. The banana peel and its ingredient lupenone showed promising antihyperglycemic activity. The banana peel could be utilized as a natural source of antihyperglycemic food, health care or drug and lupenone has potential to develop as an antihyperglycemic drug.

\section{Introduction}

Banana is one of people's favorite fruit, but most of its by-product banana peel is not fully utilized. The researches on the peel of banana show that the banana peel is rich in starch, crude protein, crude fat, pectin, cellulose, hemicelluloses, total dietary fibre, and polyunsaturated fatty acids [1,2], almost all the essential amino acids in banana peel are higher than FAO standard [3]. These studies indicate that banana peel is valuable to develop as a food. In China, The banana peel has been widely used to treat dysentery, cholera, pruritus and hypertension [4].

Recently, several cycloartane triterpenes are isolated from the banana peel [5] and an antihypertensive active ingredient, 7, 8-dihydroxy-3-methyl-isochroman-4-one is isolated from the banana peel [6], Anhwange [7] analyse the contents of potassium, calcium, iron, sodium, manganese, bromine, rubium, strontium and zirconium in the banana peel. Of course, many pharmacological activities of banana peel have also been reported, such as antimicrobial activity, antioxidant activity, mutagenecity [8-10]. 
Review the literatures, the Musa sapientum. L. banana flower [11-14], Musa sp. var. elakki bale banana flower [15], M. sapientum Linn. stem juice [16], Musa paradisiacal stem juice [17], Musa sp. var. Nanjangud rasa bale banana pseudostem [18], M. paradisiacal (Linn.) banana pseudostem [19], Musa spp. ABB Group, Dongguan dajiao unripe (green) bananas [20], Musa X paradisiaca Banana leaves [21], M. paradisiacal (Linn.) leaves [22], M. paradisiacal (Linn.) roots [23], Musa sapientum banana infructescence stalks [24] and M. paradisiacal (Linn.) banana peels [19] show a promising anti-diabetic activity. In China, Fruit peel (Musa nana Lour.) is very common. Therefore, this material was selected to study its antihyperglycemic potential. In this study, the ethyl acetate and petroleum ether extracts of banana peels were evaluated by animal experiments. Furthermore in order to determine the component(s) responsible for the pharmacological activity, the active ingredients of the banana peel extracts were identified, and the antihyperglycemic activity of the ingredient was also evaluated by animal experiments.

\section{Experimental}

\section{Instrumentation and general techniques}

NOVA-400MHz superconducting NMR spectrometer (Varian Company), TMS as internal standard; HP-5973 mass spectrometer (Hewlett-Packard); X-4-type melting point apparatus (Beijing Tech Instruments Co., Ltd.); column chromatography on silica gel (200 to $300 \mathrm{mesh}$ ) and thin layer chromatography on silica gel H, silica gel GF254 were purchased from Qingdao Haiyang Chemical Co., Ltd. All other chemicals and solvents were analytical grade and used without further purification.

\section{Plant material and reagent}

Metformin was produced by Guizhou Tian'an Pharmaceutical Co., Ltd. (Guizhou, China). Alloxan was purchased from Sigma-Aldrich Co., Ltd. (St Louis, MO, USA). Ethyl acetate (EtOAc) and petroleum ether (PE) were produced by Chengdu Kelong Chemical Reagent Factory (Sichuan, China). Absolute ethyl alcohol was purchased from Shanghai Zhenxing Chemcial No.1 Factory (Shanghai, China).Banana peel were collected in June 2013 in Guiyang, China, and confirmed as the peel of banana (Musa nana Lour.) by Dr. Xiangpei Wang. All voucher specimens were deposited in the Department of Pharmacognosy, Guiyang College of Traditional Chinese Medicine, China.

\section{Animals}

Kunming mice of either sex (15-30g) were obtained from Chongqing Tengxin Biological Technology Co., Ltd. (Chongqing, PR China; qualified number: SCXK Chongqing 2007001). The colony was maintained under controlled conditions of temperature at $23 \pm 2{ }^{\circ} \mathrm{C}, 60-70 \%$ humidity and a $12-\mathrm{h}$ light-dark cycle. All the animals in the study were cared for and treated humanely according to the national legislations of China, as well as local guidelines. The animal experiments were approved by the Ethics Committee for Animal Experiments of Guiyang College of TCM.

\section{Extraction and isolation}

The fresh banana peel was cut into small pieces and then extracted with $95 \%$ ethanol (plant material: solvent, 1:6, w/v) five times under soak for $24 \mathrm{~h}$. The extract was concentrated in vacuo at $65^{\circ} \mathrm{C}$ to give a brown gum. The brown gum was suspended in distilled water and extracted with petroleum ether (PE) eight times to afford a water layer and petroleum ether extract (PBP). Then the water layer extracted with ethyl acetate (EtOAc) eight times to afford ethyl acetate extract (EBP). The petroleum ether and ethyl ac etate extracts were concentrated in vacuo until no residual reagents. The EBP was further purified yield compounds I and II. The ethyl acetate extract was dispersed in PE and then 
submitted to column chromatography on silica gel (200-300 mesh), eluting with PE, and then eluted with EtOAc/PE (100:1), to afford a new compound I (Fig. 1). Another new compound II (Fig.1) was obtained by eluting with EtOAc/PE (10:1).

\section{Spectroscopic and spectrometric data}

Compound I: White amorphous powder; mp 170 $172^{\circ} \mathrm{C}$; EI-MS m/z: $424[\mathrm{M}]+, 409,381,367,245$, 219, 189; 1H-NMR (CDCl3, $400 \mathrm{MHz}): \delta 4.68(\mathrm{~d}, 1), 4.56(\mathrm{~d}, 1.68), \delta 1.07(6 \mathrm{H}, \mathrm{s}, 2 \times \mathrm{CH} 3), \delta$ 1.67 ( s), 1.08 (s), 1.04 (s), 0.96 (s), 0.94 (s).; 13C-NMR (CDCl3, $125 \mathrm{MHz})$ : d 213.4, 150.2, 109.4, 52.2, 49.9, 48.7, 47.1, 46.0, 45.3, 41.6, 41.0, 36.0, 35.4, 33.9, 32.8, 32.7, 31.4, 29.7, 29.2, 28.0, 27.2, $27.0,25.9,24.9,20.2,19.1,18.6,18.3,17.9,10.7[23,25]$.

Compound II: white needles; mp $138 \sim 140^{\circ} \mathrm{C}$; EI-MS m/z: $414[\mathrm{M}]+, 396,381,329,303,233,259$, 43; 1H-NMR (400MHz, CDCl3) $\delta: 5.36(\mathrm{~d}, 4.8), 3.53(\mathrm{~m}), 0.68(\mathrm{~s}), 0.82(\mathrm{~d}, 7.5), 0.84(\mathrm{~d}, 7.0), 0.86$

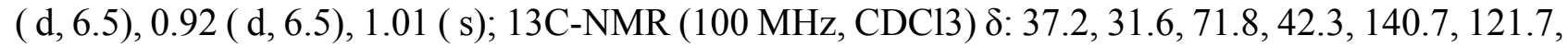
$31.9,31.9,50.1,36.1,21.1,28.2,42.3,56.7,24.3,39.7,56.0,12.0,19.4,36.5,18.8,33.9,26.0,45.8$, $29.1,19.0,19.7,23.1,11.8[26,27]$.

\section{Induction of diabetes in Kunming mice and studying of antihyperglycemic effect of EBP, PBP and lupenone}

Diabetic mices were developed as described by Ozbek et al [28] and Raafat et al [29] briefly, overnight fasted mices were intravenous injection of alloxan dissolved in sterile cold saline $(0.9 \%)$ every 48 -h for two times at $220 \mathrm{mg} / \mathrm{kg}$ and $200 \mathrm{mg} / \mathrm{kg}$, separately. Fasting glucose levels in the blood samples obtained from the tail of each mice $72 \mathrm{~h}$ after the last alloxan injection was measured with One Touch Ultra Glucose Monitor (Lifescan) (OneTouch Ultra (Johnson\&Johnson Medical (China) Ltd., China), animals with the serum glucose level above $11.11 \mathrm{mmol} / \mathrm{L}$ (diabetic) were selected for the following experiments.

In the first test, mice were divided into seven groups, including normal group, a moderately diabetic control group (10 mice per group), two diabetic groups administered EPB orally $(6.0 \mathrm{mg} / \mathrm{kg}$ and $12.0 \mathrm{mg} / \mathrm{kg}, 10$ mice per group), two diabetic groups administered PBP orally $(6.0 \mathrm{mg} / \mathrm{kg}$ and $13.0 \mathrm{mg} / \mathrm{kg}, 10$ mice per group), one diabetic group administered metformin $(300.0 \mathrm{mg} / \mathrm{kg}, 10 \mathrm{mice})$. Blood samples were collected from the tail vein for the measurement of blood glucose at 7 and $14 \mathrm{~d}$ after administration.

In the second test, mice were divided into four groups, including normal group, one moderately diabetic control (10 mice per group), one diabetic groups administered lupenone orally (12.0 mg/kg, 10 mice per group), and one diabetic group administered metformin $(300.0 \mathrm{mg} / \mathrm{kg}, 10 \mathrm{mice})$. Blood samples were collected from the tail vein for the measurement of blood glucose at $14 \mathrm{~d}$ after administration.

\section{Statistical analysis}

All results are presented as the mean \pm S.D. The data were analyzed for statistical significance by one-way ANOVA test. Results were considered significant at $\mathrm{p}<0.05$. 


\section{Results and Discussion}

\section{Antihyperglycemic effect of EBP and PBP in alloxan-induced diabetic mice}

None of the animals died during the experiment. The effects of EBP on blood glucose levels of alloxan-induced diabetic mice were shown in Table 1 . On day 7 , only EBP $(12.0 \mathrm{mg} / \mathrm{kg})$ group can significantly lower blood glucose $(p<0.05)$ compared to diabetes control group. When on day 14 , the results showed that all the EBP groups significantly lowered blood glucose levels in diabetic mice ( $p$ $<0.05)$. The effects of PBP on blood glucose levels in diabetic mice were also listed in Table 1 . The results displayed that the PBP did not reduce the blood glucose levels in alloxan-induced diabetic mice on day 7 and day 14 . So EBP was selected to isolate the antihyperglycemic ingredients. Vijai and others (2014) reported that ethanolic extracts and the hexane and chloroform fractions of banana (M. paradisiacal (Linn.)) peels showed promising anti-diabetic activity in STZ-induced diabetic rats, but the anti-diabetic activity of ethyl acetate and petroleum ether extract of banana peel did not evaluate. We found the EBP (Musa nana Lour.) had the antihyperglycemic activity, too.

Table1. The Antihyperglycemic effect of EBP and PBP in alloxan-induced diabetic mice $(n=10)$

\begin{tabular}{llll}
\hline Groups & \multicolumn{3}{c}{ Blood glucose(mmol/l) } \\
\cline { 2 - 4 } & Initial & $7 \mathrm{~d}$ & $14 \mathrm{~d}$ \\
\hline Normal control & $4.71 \pm 0.89$ & $5.73 \pm 0.48$ & $5.20 \pm 0.58$ \\
Diabetic control & $20.28 \pm 3.76$ & $13.87 \pm 3.83$ & $17.01 \pm 4.85$ \\
Metformin(300.0 mg/kg) & $19.15 \pm 4.33$ & $10.61 \pm 3.39$ & $12.09 \pm 3.47^{*}$ \\
EBP(6.0 mg/kg) & $18.63 \pm 4.25$ & $10.50 \pm 4.86$ & $11.41 \pm 4.20^{*}$ \\
EBP(12.0 mg/kg) & $19.39 \pm 4.29$ & $10.36 \pm 2.97^{*}$ & $12.33 \pm 3.75^{*}$ \\
PBP(6.0 mg/kg) & $19.58 \pm 3.44$ & $13.14 \pm 3.27$ & $14.91 \pm 4.81$ \\
PBP(13.0 mg/kg) & $19.31 \pm 4.66$ & $12.68 \pm 3.82$ & $15.17 \pm 4.34$ \\
\hline
\end{tabular}

The normal control and diabetic control group received $0.2 \mathrm{ml} / 10 \mathrm{~g}$ water orally daily. Values are means \pm S.D., $* \mathrm{p}<0.05, * * \mathrm{p}<0.01$ compared with the diabetic control group.

\section{Identification of the chemical compounds from EBP}

Structures of the isolates (Fig.1) were deduced by comparison of their mp, EI-MS, 1H- and 13C-NMR with the literature data, revealed that compoundIis lupenone, compound II is $\beta$-sitosterol. Our results represented the first report of isolation of lupenone from banana peel. The $\beta$-sitosterol has been yeilded from banana peel reported by Matook S M and Fumio H [30]. 

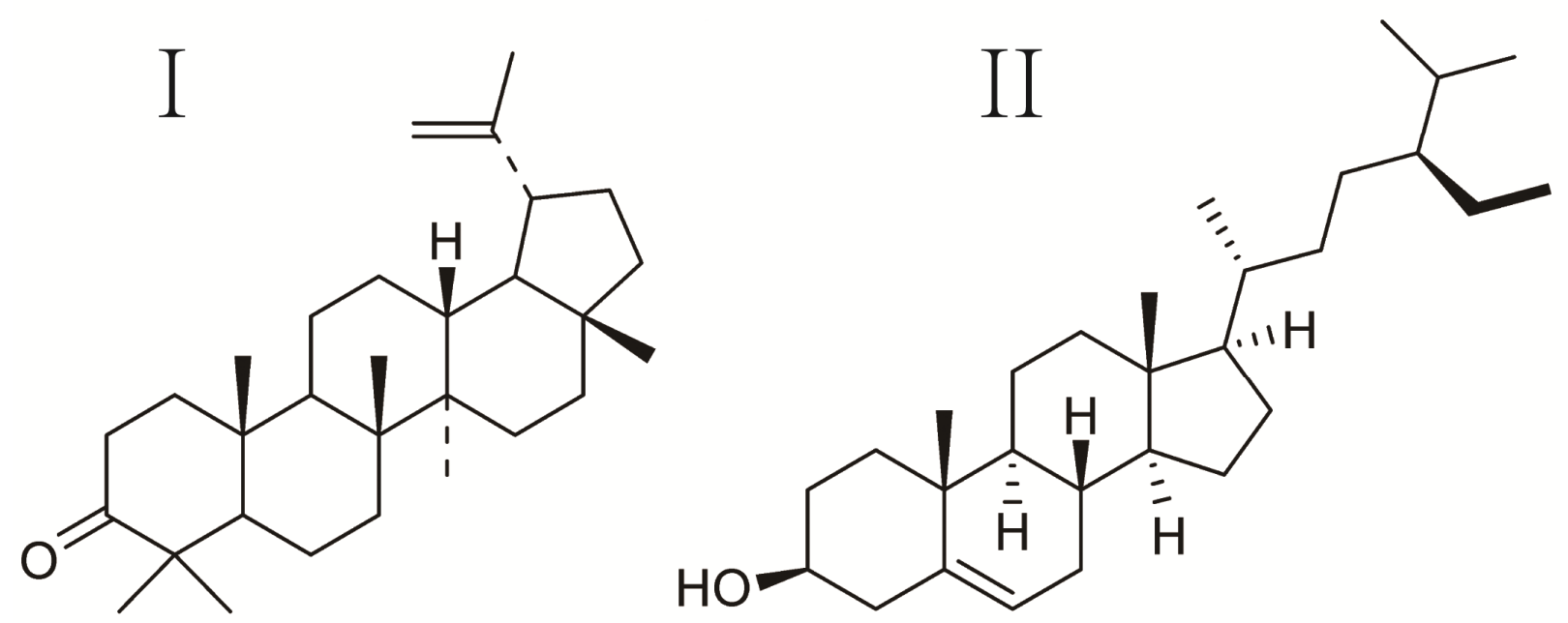

Fig. 1. Chemical structure of the lupenone (I) and $\beta$-sitosterol(II)

\section{Antihyperglycemic effect of lupenone in diabetic mice}

As the results showed in Table 2, lupenone from EBP had significant antihyperglycemic activity ( $p$ $<0.01$ ), which showed that lupenone was one of the antihyperglycemic active ingredients of banana peel. According to reports, lupenone can inhibit a -glucosidase $(\alpha-\mathrm{Glu})$ and protein tyrosine phosphatase 1B (PTP1B) activity in vitro [31, 32], the two enzymes are associated with anti-diabetic, and recently study has found that lupenone has the anti-diabetic activity in diabetic sprague-dawley rats [33]. In this study, the results clearly showed that lupenone had a significantly antihyperglycemic activity in alloxan-induced diabetic mice with no animal deaths during the experiment. And Gupta and others [34] reported that $\beta$-sitosterol have potential of anti-diabetic and anti-oxidant in streptozotocin-induced experimental hyperglycemia. The lupenone and $\beta$-sitosterol yielded from EBP were the antihyperglycemic active ingredients of banana peel. The lupenone also has been isolated from ethyl acetate fraction of Rhizoma Musae (the dried rhizome of Musa basjoo Sieb. et Zucc.), the lupenone may exist in Musaceae family.

Table2. The Antihyperglycemic effect of lupenone in alloxan-induced diabetic mice $(n=10)$

\begin{tabular}{lll}
\hline Groups & \multicolumn{2}{c}{ Blood glucose $(\mathrm{mmol} / \mathrm{l})$} \\
\cline { 2 - 3 } & Initial & $14 \mathrm{~d}$ \\
\hline Normal control & $3.84 \pm 0.36$ & $3.70 \pm 0.38$ \\
Diabetic control & $15.45 \pm 3.16$ & $14.33 \pm 2.40$ \\
Metformin $(300.0 \mathrm{mg} / \mathrm{kg})$ & $15.03 \pm 3.25$ & $9.10 \pm 2.59 * *$ \\
Lupenone $(12.0 \mathrm{mg} / \mathrm{kg})$ & $13.63 \pm 1.68$ & $8.93 \pm 3.10^{* *}$ \\
\hline
\end{tabular}

The normal control and diabetic control group received $0.2 \mathrm{ml} / 10 \mathrm{~g}$ water orally daily. Values are means \pm S.D., $* \mathrm{p}<0.05, * * \mathrm{p}<0.01$ compared with the diabetic control group.

\section{Conclusions}

The present study indicated that the EBP and lupenone had significant antihyperglycemic activity. lupenone was first time isolated from banana peel, and the banana peel could be utilized as a natural source of antihyperglycemic food, health care or drug. lupenone have potential to develop as an anti-diabetic drug. 


\section{Author Contributions}

Dr. Hongmei Wu and Feng Xu contributed equally to this work. They conduct this study. Dr Xiangpei Wang design this study, revising the draft, interpretation of the results, Junjie Hao and Ye Yang analysis the data and revise the draft.

\section{Acknowledgments}

This work was supported by NSFC (30860387), the Special Funds of Outstanding Young Scientists in Guizhou, PR China (2013, NO.46), and Guizhou province traditional Chinese medicine (TCM) modernization research projects (department of Guizhou in ZY (2012) 2016).

\section{References}

[1] Happi Emaga T, Andrianaivo, RH, Wathelet B, Tchango JT, \& Paquot M., Effects of the stage of maturation and varieties on the chemical composition of banana and plantain peels, Food chem. 103(2007): 590-600.

[2] Happi Emaga T, Robert C, Ronkart SN, Wathelet B, \& Paquot M., Dietary fibre components and pectin chemical features of peels during ripening in banana and plantain varieties, Bioresource Technol. 99(2008): 4346-4354.

[3] Mohapatra D, Mishra S, \& Sutar N., Banana and its by-product utilization: an overview, J Sci Ind Res. 69(2010): 323-329.

[4] State administration of traditional chinese medicine, Chinese Materia Medica, Shanghai, 1999. (In Chinese)

[5] Akihisa T, Kimura Y, Tamura T., Cyclotrane triterpenes from the fruit peel of Musa sapientum, Phytochemistry. 47 (1998): 1107-1110.

[6] Qian H, Huang WL, Wu XM, Zhang HB, Zhou JP, Ye WC., A new isochroman-4-one derivative from the peel of Musa sapientum L. and its total synthesis, Chinese Chem Lett. 18 (2007): 1227-1230.

[7] Anhwange BA., Chemical composition of Musa sapientum (banana) peels, J Food Technol. 6 (2008): 263-266.

[8] Alisi CS, Nwanyanwu CE, Akujobi CO, Ibegbulem CO., Inhibition of dehydrogenase activity in pathogenic bacteria isolates by aqueous extracts of Musa paradisiaca (Var Sapientum), Afr J Biorechnol. 7 (2008): 1821-1825.

[9] Kandasamy S, Baggu C, Javagal M R, Lingamallu J R, Yenamandra V, \& Aradhya SM., Antioxidant Properties of Isolated Compounds from Banana Rhizome, J food sci. 79(2014): H988-H1001.

[10] Andrade CUB, Perazzo FF, Maistro EL., Mutagenicity of the Musa paradisiaca (Musaceae) fruit peel extract in mouse peripheral blood cells in vivo, Genet Mol Res. 7 (2008):725-732.

[11] Alarcon-Aguilara FJ, Roman-Ramos R, Perez-Gutierrez S, Aguilar-Contreras A, Contreras-Weber C. C, Flores-Saenz JL., Study of the anti-hyperglycemic effect of plants used as antidiabetics, J Ethnopharmacol. 61 (1998): 101-110.

[12] Pari L, Umamaheswari J., Hypoglycaemic effect of Musa sapientum L. in alloxan-induced diabetic rats, J Ethnopharmacol. 68 (1999): 321-325.

[13] Pari L, Umamaheswari J., Antihyperglycaemic activity of Musa sapientum flowers: effect on lipid peroxidation in alloxan diabetic rats, Phytother Res. 14 (2000): 136-138. 
[14] Ganugapati J, Baldwa A, Lalani S., Molecular docking studies of banana flower flavonoids as insulin receptor tyrosine kinase activators as a cure for diabetes mellitus, Bioinformation. 8(2012.): 216.

[15] Bhaskar JJ, Shobha MS, Sambaiah K, \& Salimath PV., Beneficial effects of banana (Musa sp. var. elakki bale) flower and pseudostem on hyperglycemia and advanced glycation end-products (AGEs) in streptozotocin-induced diabetic rats, J Physiol Biochem. 67 (2011): 415-425.

[16] Dikshit P, Shukla K, Tyagi MK, Garg P, Gambhir JK, \& Shukla R., Antidiabetic and antihyperlipidemic effects of the stem of Musa sapientum Linn. in streptozotocin-induced diabetic rats, J diabetes. 4(2012): 378-385.

[17] Singh SK, Kesari AN, Rai PK, \& Watal G., Assessment of glycemic potential of Musa paradisiaca stem juice, Indian J Clin Biochem. 22 (2007): 48-52.

[18] Ramu R, Shirahatti PS, Zameer F, \& Prasad N., Investigation of antihyperglycaemic activity of banana (Musa sp. var. Nanjangud rasa bale) pseudostem in normal and diabetic rats, J SCI Food Agric. 95(2014): 165-173.

[19] Lakshmi V, Agarwal SK, Ansari JA, Mahdi AA, \& Kumar A., Antidiabetic potential of Musa paradisiaca in Streptozotocin-induced diabetic rats, JPHYTO. 3 (2014): 77-81.

[20] Yongliang B, Ming Y, Bing D, Qingfa C, \& Gongming Y., Modulation of fasting blood glucose by raw banana powder in alloxan-induced diabetic rats,mInt J Agric \& Biol Eng. 6 (2013): 94-102.

[21] Kappel VD, Cazarolli LH, Pereira DF, Madoglio FA, Buss ZDS, Reginatto FH, \& Silva FR., Beneficial effects of banana leaves (Musa X paradisiaca) on glucose homeostasis: multiple sites of action, Rev Bras Farmacogn. 23 (2013):706-715.

[22] Jaber H, Baydoun E, Ola EZ, \& Kreydiyyeh SI., Anti-hyperglycemic Effect of the Aqueous Extract of Banana Infructescence Stalks in Streptozotocin-induced Diabetic Rats, Plant Food Hum Nutr. 68 (2013): 83-89.

[23] Dai Z, Wang F, Wang GL, Lin RC., Studies on chemical constituents of Balanophora spicata, Chin J Chin Mater Med. 31 (2006): 1798-1800.(In Chinese)

[24] Jaber H, Baydoun E, Ola EZ, \& Kreydiyyeh SI., Anti-hyperglycemic Effect of the Aqueous Extract of Banana Infructescence Stalks in Streptozotocin-induced Diabetic Rats, Plant Food Hum Nutr. 68 (2013): 83-89.

[25] Ahn EK, Oh JS., Lupenone isolated from adenophora triphylla var. japonica extract inhibits adipogenic differentiation through the downregulation of PPAR $\gamma$ in 3T3-L1 Cells, Phytother Res. 27 (2013): 761-766.

[26] Karan SK, Mishra SK, Pal D, Mondal A., Isolation of $\beta$-sitosterol and evaluation of antidiabetic activity of Aristolochia indica in alloxan-induced diabetic mice with a reference to in-vitro antioxidant activity, J Med Plant Res. 6 (2012): 1219-1223.

[27] Babalola IT, Adelakun EA., Isolation of stigmast-5-en-3 $\beta$-ol ( $\beta$-sitosterol) from dichloromethane extract of Sterculia setigera Leaves (Sterculiaceae), Arch Appl Sci Res 5 (2013):16-19.

[28] Ozbek H, Ceylan E, Kara M, Özgökçe F, Koyuncu M., Antihyperglycemic effect of Rheum ribes roots in alloxan induced diabetic and normal mice, Scand J Lab Anim Sci. 31 (2004): 113-115.

[29] Raafat K, Aboul-Ela M, El-Lakany A., Alloxan-induced diabetic thermal hyperalgesia, prophylaxis and phytotherapeutic effects of Rheum ribes L. in mouse model, Arch Pharm Res. (2014): $1-10$.

[30] Matook SM, Fumio H., Antibacterial and antioxidant activities of banana (Musa, AAA cv. Cavendish) fruits peel, Am J Biochem \& Biotechnol. 1 (2005): 125-131. 
[31] Mohamed, IE, El Nur EBE, Choudhary MI, Khan SN., Bioactive natural products from two sudanese medicinal plants diospyros mespiliformis and croton zambesicus, Rec Nat Prod. 3 (2009): 198-203.

[32] Na M, Kim BY, Osada H, Ahn JS., Inhibition of protein tyrosine phosphatase 1B by lupeol and Lupenone isolated from Sorbus commixta, J Enzyme Inhib Med Chem. 24 (2009): 1056-1059.

[33] Xu, F., Wu, H., Wang, X. P., Yang, Y., Wang, Y. M., Qian, H. B., Zhang Y. Y., RP-HPLC Characterization of Lupenone and $\beta$-Sitosterol in Rhizoma Musae and Evaluation of the Anti-Diabetic Activity of Lupenone in Diabetic Sprague-Dawley Rats, Molecules. 19 (2014): 14114-14127.

[34] Gupta R, Sharma AK, Dobhal MP, Sharma MC, Gupta RS., Antidiabetic and antioxidant potential of $\beta$-sitosterol in streptozotocin-induced experimental hyperglycemia, J Diabetes. 3 (2011): 29-37. 